\author{
DAGMARA GRUSZECKA \\ ORCID: 0000-0003-3370-7902 \\ Uniwersytet Wrocławski \\ Katedra Prawa Karnego Materialnego
}

\title{
O NIEKTÓRYCH PROBLEMACH Z WYZNACZANIEM GRANICY MIĘDZY ODPOWIEDZIALNOŚCIĄ POTENCJALNEGO SPRAWCY A POKRZYWDZONEGO W KONCEPCJI OBIEKTYWNEGO PRZYPISANIA SKUTKU
}

\begin{abstract}
Abstrakt: Przyjmowana w doktrynie prawa karnego koncepcja obiektywnego przypisania skutku ma stanowić dodatkowy filtr w badaniu samej przyczynowości, oparty na kryteriach stworzenia przez potencjalnego sprawcę bezprawnego ryzyka dla dobra prawnego i urzeczywistnienia się tegoż właśnie niebezpieczeństwa w danym, należącym do znamion, skutku. Stosowanie tej formuły przypisywalności staje się jednak szczególnie problematyczne w konfiguracjach wieloosobowych, gdy ostateczne niebezpieczeństwo powstaje w wyniku kumulacji zachowań różnych podmiotów, w tym samego pokrzywdzonego. Niniejszy artykuł koncentruje się na kryteriach określania zakresu odpowiedzialności w takich układach i jest propozycją uzupełnienia porównań czysto ilościowych. W odniesieniu do tej kwestii przedstawione zostały też rozważania autorów niemieckich, zwłaszcza odnoszące się do zagadnienia autonomii w podejmowaniu decyzji przez dysponenta dobra prawnego.
\end{abstract}

Słowa kluczowe: prawo karne, koncepcja obiektywnego przypisania skutku w prawie karnym, granice stworzenia bezprawnego ryzyka, pokrzywdzony, odpowiedzialność karna dysponenta dobrem prawnym

Chociaż zasadnicza problematyka przypisania odpowiedzialności karnej za skutek przedstawiana zostaje zwykle w schemacie linearnym, w którym ma służyć ostatecznemu rozstrzygnięciu, czy dana zmiana w rzeczywistości należąca do znamion typu czynu zabronionego może zostać normatywnie powiązana z zachowaniem już wyodrębnionego kandydata na sprawcę, to całkowicie „wypreparowane" z interferencji czynów innych osób, czyste relacje wyłącznie między jednostką a określonym negatywnie wartościowanym stanem rzeczy zdarzają się, poza światem podręcznikowych kazusów, niezmiernie rzadko ${ }^{1}$. Zagadnienia związane

${ }^{1}$ Por. J. Giezek, [w:] System Prawa Karnego, t. 3. Nauka o przestępstwie. Zasady odpowiedzialności, red. R. Dębski, wyd. 2, Warszawa 2017, s. 509; I. Goeckenjan, Revision der Lehre von der objektiven Zurechnung, Tübingen 2017, s. 183. 
z nakładaniem się na siebie nieostrożnych z perspektywy ochrony dóbr prawnych działań lub zaniechań poszczególnych podmiotów, których autonomiczne udziały w ostatecznie wygenerowanym ryzyku rodzą pytanie o rozgraniczanie zakresów ich odpowiedzialności karnej, nadal pozostają jednym z mniej wyeksplorowanych obszarów karnistyki, co skutkuje zdecydowaną przewagą zgłaszanych wątpliwości nad liczbą satysfakcjonujących odpowiedzi².

Przyczyn takiego stanu rzeczy można by próbować wymienić przynajmniej kilka: od oporów przed cywilistycznym zakorzenieniem instytucji „przyczynienia się” i w zasadniczych punktach niepodważalnej wszak odmienności między elastycznym mechanizmem miarkowania odpowiedzialności za szkodę (pozwalających nawet na ujmowanie jej w kategoriach procentowych) a zasadniczo binarnym charakterem rozstrzygnięć w prawie karnym, przyjmujących postać orzeczenia o odpowiedzialności za dany rezultat lub o jej braku, nie zaś o jakiejś odpowiedzialności, po przesunięcia zagadnień tak zwanej kolizji odpowiedzialności za skutek na dodatkowy poziom obiektywnego przypisania jako tak zwanych kryteriów negatywnych, tym samym zaś — kryteriów „partykularnych”“3 czy „,szczególnego przeznaczenia”“4 Na-

${ }^{2}$ Nawet przy wskazaniu niezwykle istotnych opracowań, jak te autorstwa przede wszystkim M. Bielskiego, R. Dębskiego, J. Giezka, J. Majewskiego, M. Małeckiego, P. Kardasa, T. Sroki czy S. Tarapaty. Zob. M. Bielski, Obiektywne przypisanie skutku przestępnego w przypadku kolizji odpowiedzialności za skutek, „Państwo i Prawo” 2005, nr 10, s. 78; idem, Kryteria obiektywnego przypisania skutku na tle współczesnej polskiej dogmatyki prawa karnego, [w:] Państwo prawa i prawo karne. Księga jubileuszowa Profesora Andrzeja Zolla, red. P. Kardas, T. Sroka, W. Wróbel, t. 2, Warszawa 2012, s. 514 n.; R. Dębski, Jeszcze o propozycji zakotwiczenia w kodeksie karnym kryteriów obiektywnego przypisania skutku, „Nowa Kodyfikacja Prawa Karnego” 43. Księga jubileuszowa Profesora Tomasza Kaczmarka, red. J. Giezek, D. Gruszecka, T. Kalisz, 2017, s. 66 n.; J. Giezek, Przyczynowość oraz przypisanie skutku w prawie karnym, Wrocław 1994, s. 146 n.; idem, [w:] System Prawa Karnego, t. 3, s. 509; J. Majewski, Prawnokarne przypisanie skutku przy zaniechaniu (zagadnienia węzłowe), Kraków 1997; T. Sroka, Odpowiedzialność karna za niewłaściwe leczenie. Problematyka obiektywnego przypisania skutku, Warszawa 2013; S. Tarapata, Przypisanie sprawstwa skutku w sensie dynamicznym w polskim prawie karnym, Kraków 2019; oraz teksty wymienionych autorów w Obiektywne oraz subiektywne przypisanie odpowiedzialności karnej, red. J. Giezek, P. Kardas, Warszawa 2016.

3 J. Giezek, P. Kardas, O kryteriach obiektywnego oraz subiektywnego przypisania z punktu widzenia podstaw odpowiedzialności karnej - uwagi wprowadzające, [w:] Obiektywne oraz subiektywne przypisanie..., s. 29.

${ }^{4} \mathrm{Z}$ uwagi na autorytet C. Roxina, niewątpliwie jednego z ojców założycieli nauki o obiektywnym przypisaniu (por. idem, Strafrecht. Allgemeiner Teil, t. 1. Grundlagen. Der Aufbau der Verbrechenslehre, München 2006, s. 401 n.), stanowisko o trzyszczeblowym modelu przypisania, mimo że stanowi pogląd mniejszościowy, nadal odznacza się jednak pewną żywotnością (por. aprobująco: M. Heinrich, [w:] Nomos Kommentar. Gesamtes Strafrecht, red. D. Dölling et al., Baden-Baden 2017, s. 177 n.). W wyraźnej inspiracji ideą stratyfikacji przypisania i wyróżnianiem dla układów wieloosobowych kryteriów negatywnych w rodzimej dogmatyce swoją koncepcję rozwiązywania sytuacji tak zwanej kolizji odpowiedzialności za skutek przedstawił zaś M. Bielski (por. idem, Obiektywne przypisanie..., s. 78-79; idem, O potrzebie teoretycznej, dogmatycznej i kryminalnopolitycznej refleksji nad negatywnymi przesłankami obiektywnego przypisania skutku przestępnego, [w:] Obiektywne oraz subiektywne przypisanie..., s. 264-265; idem, Kryteria obiektywnego 
wet jednak na tle tej skali trudności ${ }^{5}$ szczególnie problematycznie prezentują się te warianty układów wieloosobowych, w których jedną z jednostek podejmujących się ryzykownego zachowania jest sam dysponent następnie zagrożonych lub naruszonych dóbr prawnych, a bez jego „zaangażowania” skutek albo wcale nie zostałby wywołany, albo przybrałby inną postać od tej, w której faktycznie zaistniał.

Analiza wypowiedzi prezentowanych w piśmiennictwie pozwala na wysunięcie tezy, że całość poszukiwań przesłanek rozgraniczenia sfer ryzyka i przypisania w prawie karnym, z jednej strony, uwikłana jest w paradygmat odpowiedzialności jedynie za następstwa własnych zachowań ${ }^{6}$, z drugiej zaś — sprowadza się do próby uchwycenia istoty jakiegoś rodzaju ,przewagi”, która miałaby w badanym przebiegu przyczynowym wystąpić po stronie jednego z kandydatów do przypisania, z uwagi na konieczność legitymacji ryczałtowego wszak obciążenia go całością następstw ${ }^{7}$, a zatem także tych wygenerowanych przez pozostałe podmioty. Kolizyjność tych dwóch kierunków (to jest „każdy za swoje”, a zarazem ,jeden za wszystko"), przy specyfice interesującego nas zagadnienia kombinacji zachowań osoby trzeciej i dysponenta dobra prawnego, wymaga dodatkowego uwzględnienia wpływu na prawnokarne wartościowanie braku czy niedostatecznego zainteresowania ochroną własnych dóbr przez samą „ofiarę”. W zaproponowanej przez

przypisania..., s. 514; ostatnio jednak przyznając podziałowi jedynie „charakter porządkujący”). Ponieważ nie ma tu miejsca na nawet syntetyczną rekapitulację zasadniczych punktów krytyki stratyfikacji przesłanek obiektywnego przypisania, pozostaje odesłanie do obszernej argumentacji w literaturze - por. zwłaszcza R. Dębski, O tzw. negatywnych przesłankach obiektywnego przypisania, [w:] Obiektywne oraz subiektywne przypisanie..., s. 213; idem, O potrzebie kodeksowych przepisów o obiektywnym przypisaniu skutku, [w:] Meandry prawa karnego i kryminalistyki. Księga jubileuszowa prof. zw. dra hab. Stanisława Pikulskiego, red. J. Kasprzak, W. Cieślak, I. Nowicka, Szczytno 2015, s. 76; P. Kardas, W poszukiwaniu tzw. negatywnych kryteriów obiektywnego przypisania, [w:] Obiektywne oraz subiektywne przypisanie..., s. 270; J. Giezek, T. Kaczmarek, Przeciwko ustawowej regulacji kryteriów obiektywnego przypisania skutku, „Państwo i Prawo” 2013, nr 5, s. 87 n.; oraz najnowsza obszerna analiza - S. Tarapata, op. cit., s. 355 n.

5 J. Giezek zaznacza wręcz sceptycznie, że droga do uczynienia z przesłanek kumulacji zachowań ryzykownych powszechnie stosowanych kryteriów obiektywnego przypisania ,jest jeszcze bardzo daleka" - J. Giezek, [w:] System Prawa Karnego, t. 3, s. 521. Tożsame konkluzje formułują zresztą autorzy niemieccy.

${ }^{6}$ Zob. podkreślenie znaczenia tej zasady dla rozgraniczania zakresów odpowiedzialności karnej oraz jej dwóch możliwości rozumienia - ibidem, s. 511; M. Bielski, O potrzebie..., s. 267-268; P. Kardas, op. cit., s. 270.

7 Konieczność ta wynika właśnie z niemożności wspomnianej realizacji znamion typu (znamienia skutku) jedynie częściowo (będzie jednak jeszcze mowa o odpowiedzialności jedynie za narażenia na niebezpieczeństwo), na podobieństwo częściowej odpowiedzialności za szkodę, przy czym przez tego rodzaju „obciążenie” należy — precyzyjniej — rozumieć lokację ryzyka i sprawstwa po stronie danego podmiotu. Kwestia obciążenia rozumianego jako ukaranie i jego konkretny wymiar jest już bowiem nieco innym zagadnieniem. Dlatego też na etapie ukarania może wystąpić odpowiednie „miarkowanie” odpowiedzialności, jako że inne szczeble struktury przestępstwa, jak wina czy społeczna szkodliwość, są jak najbardziej stopniowalne. 
M. Bielskiego koncepcji rozwiązywania „kolizji odpowiedzialności za skutek”8 mechanizm wartościowania opiera się na wprowadzeniu uniwersalnego kryterium normatywnego, jakim ma być

porównanie charakteru i stopnia naruszonych przez potencjalnego sprawcę i osobę trzecią lub pokrzywdzonego reguł postępowania z dobrem prawnym oraz ustalenie, jakie przełożenie na wystąpienie skutku przestępnego w jego konkretnej postaci miało każde z zachowań sprzecznych $\mathrm{z}$ wymaganymi w danym układzie regułami zachowanie ${ }^{9}$.

Jedynie ocena, że w skutku urzeczywistniło się przede wszystkim ryzyko jego spowodowania wynikające $\mathrm{z}$ obiektywnie nieprawidłowego zachowania osoby pokrzywdzonego (lub osób trzecich), ,pozwala na obciążenie odpowiedzialnością za spowodowanie skutku przestępnego wyłącznie osobę trzecią (często samego pokrzywdzonego)" $10 \mathrm{i}$ to pomimo faktu, że bezprawne zachowanie potencjalnego sprawcy też było normatywnie relewantne dla wystąpienia skutku przestępnego.

$\mathrm{W}$ innych publikacjach ${ }^{11} \mathrm{M}$. Bielski możliwe rozwiązania w odniesieniu do osoby pokrzywdzonego w tak zwanych układach dynamicznego niebezpieczeństwa grupuje w cztery klasy przypadków. Pierwsza obejmuje tego rodzaju proporcję między poziomem niebezpieczeństwa sprowadzenia skutku wytworzonym przez potencjalnego sprawcę a stworzonym przez pokrzywdzonego, że nastąpienie naruszenia dobra prawnego staje się wynikiem przede wszystkim (choć oczywiście nie wyłącznie) tego pierwszego, podczas gdy bezprawne zachowanie się pokrzywdzonego, pozostając koniecznym elementem wystąpienia skutku, stanowi w istocie naruszenie normy o znacznie mniejszym znaczeniu. Przy braku podstaw do wyłączenia obiektywnego przypisania tegoż skutku potencjalnemu sprawcy jego odpowiedzialność karna może w wyniku zachodzącego jednak ,przyczynienia się" pokrzywdzonego ulec złagodzeniu przez uznanie wpływu innego podmiotu za okoliczność zmniejszającą winę lub stopień przypisywanego sprawcy bezprawia.

${ }^{8}$ Należałoby tu poczynić pewne zastrzeżenie dotyczące rozumienia kategorii „kolizji odpowiedzialności za skutek”. Początkowo M. Bielski widział w niej jeszcze jedną z przesłanek obiektywnego przypisania, o którą należałoby uzupełnić katalog kryteriów negatywnych zaproponowany przez C. Roxina. Miała być to zatem przesłanka dodatkowa (dla układów tak zwanego dynamicznego niebezpieczeństwa), nie zaś zbiorcza, łącząca w sobie wszystkie przypadki wiązane z kryteriami negatywnymi (tak: M. Bielski, Obiektywne przypisanie..., s. 81). Obecnie można odnieść wrażenie, że autor proponuje jednak rozciągnąć wskazywaną przesłankę na wszystkie przypadki, „w których pomimo możliwości powiązania bezprawnego zachowania sprawcy ze skutkiem przestępnym, uzasadnione miałoby być twierdzenie, że podmiotu odpowiedzialności karnej nie można uznać za wyłącznie odpowiedzialny za skutek przestępny w postaci naruszenia dobra prawnego ze względu na relewantne dla skutku zachowanie osoby trzeciej" — idem, Kryteria obiektywnego przypisania..., s. 525.

9 M. Bielski, Kryteria obiektywnego przypisania..., s. 527; idem, O potrzebie..., s. 273.

10 M. Bielski, O potrzebie..., s. 276.

11 M. Bielski, Obiektywne przypisanie..., s. 87.

Przegląd Prawa i Administracji CXX, 2020, cz. 1 i 2

(C) for this edition by CNS 
Po przeciwnej stronie umieścić należy natomiast układ, w którym porównanie rodzaju i charakteru naruszonych przez potencjalnego sprawcę oraz pokrzywdzonego norm zakazu (wywołania skutku) lub nakazu (zapobieżenia skutkowi) pozwala na ustalenie, że to bezprawne zachowanie się pokrzywdzonego okazało się dominującą okolicznością decydującą o ziszczeniu się naruszenia dobra prawnego, co przekłada się konsekwentnie na wyłączenie przypisania potencjalnemu sprawcy skutku w postaci naruszenia dobra prawnego, choć — zgodnie ze stanowiskiem autora - daje równocześnie podstawy do przypisania mu narażenia dobra na niebezpieczeństwo konkretne.

Od tej grupy należy jednak odróżnić sytuacje, w których wprawdzie to potencjalny sprawca, naruszając normę zakazu wywołania skutku przestępnego (lub nakazu zapobieżenia takiemu skutkowi), wywołał negatywne następstwo w postaci naruszenia dobra, niemniej jednocześnie będzie można uznać, że bezprawne zachowanie pokrzywdzonego wpłynęło na wystąpienie skutku dalej idącego niż ten, który miałby miejsce, gdyby pokrzywdzony zachował się zgodnie z wymaganymi od niego regułami ostrożności ${ }^{12}$. Są to zatem przypadki, w których istotność udziału pokrzywdzonego wyraża się w tym, że reaguje on na tyle nieostrożnie na zapoczątkowane przez potencjalnego sprawcę niebezpieczeństwo, że nie tylko zwiększa jego natężenie, ale wręcz powoduje odchylenie w eskalacji sytuacji ryzykowanej w taki sposób, że zamiast pierwotnego naruszenia dobra prawnego $\mathrm{X}$ dochodzi do znacznie poważniejszego naruszenia dobra prawnego Y. Ustalenie, że bez nieadekwatnego zachowania się pokrzywdzonego wystąpiłyby inne następstwa lub następstwa w znacznie mniejszych rozmiarach niż te, które rzeczywiście zaistniały, powinno - mimo uruchomienia całego łańcucha przyczynowego właśnie przez potencjalnego sprawcę — prowadzić do ograniczenia jego odpowiedzialności jedynie do przestępstwa konkretnego narażenia na niebezpieczeństwo. Zachowanie zasady odpowiedzialności wyłącznie za następstwa własnego zachowania nie pozwalałoby bowiem przypisać potencjalnemu sprawcy i tych następstw, które nie wystąpiłyby, gdyby w skutku urzeczywistniło się jedynie niebezpieczeństwo stworzone przez niego ${ }^{13}$.

12 Autor ilustruje tę kategorię dość skomplikowanym podmiotowo (oprócz ,przyczyniającego się" pokrzywdzonego i tak zwanego potencjalnego sprawcy wprowadzona zostaje bowiem pokrzywdzona osoba trzecia) przykładem kierowcy wymuszającego pierwszeństwo przejazdu, w wyniku czego inny kierujący zostaje zmuszony do wykonania nieudanego manewru omijania, ten zaś kończy się uderzeniem w słup wysokiego napięcia i śmiercią pasażerki drugiego z pojazdów. Ustalenia wskazują, że po pierwsze zarówno kierujący drugim pojazdem, jak i jego pasażerka nie mieli zapiętych pasów bezpieczeństwa, po drugie, gdyby nie podjęcie nieostrożnego manewru mijania samo zderzenie pojazdów zakończyłoby się ze znacznym prawdopodobieństwem dużo łagodniejszymi konsekwencjami.

13 Zgodnie z powyższym ,mimo ewidentnego zapoczątkowania tragicznego przebiegu przyczynowego przez kierowcę, który wymusił pierwszeństwo, nie do zaakceptowania byłoby skazywanie go za skutek w postaci naruszenia dobra, jakim było życie pokrzywdzonej, skoro z opinii biegłych wynikało, że niewykonanie manewru omijania oraz zapięcie pasów przez pokrzywdzoną 
Wreszcie czwarta grupa obejmuje przypadki swoistego „remisu”, w których zarówno bezprawne zachowanie potencjalnego sprawcy, jak i bezprawne zachowanie pokrzywdzonego w porównywalnie wysokim stopniu zaważyły na wystąpieniu skutku. Zbliżony rodzaj i charakter naruszonych przez oba podmioty norm zakazu (ewentualnie nakazu), wpływający na ustalenie podobnie silnego powiązania z naruszeniem dobra prawnego, nie pozwala na zatrzymanie przypisania na etapie narażenia na niebezpieczeństwo, lecz uzasadnia odpowiedzialność potencjalnego sprawcy za faktyczny skutek w jego pełnej postaci. Natomiast, tak jak w pierwszej grupie, zachowanie pokrzywdzonego pozostaje o tyle relewantne, że rzutuje na stopień zawinienia lub zarzucanego bezprawia.

Podsumowując zatem — przy założeniu, że wypełnienie przesłanek pozytywnych przez każdy z podmiotów (będące wszak założeniem wyjściowym dla kolizji odpowiedzialności za skutek) zawsze umożliwia przypisanie skutku w postaci narażenia dobra prawnego na konkretne niebezpieczeństwo, a jednocześnie, iż pokrzywdzony, dopóki skutek taki występuje jedynie na jego własnych dobrach, nie ponosi odpowiedzialności karnej - należy stwierdzić, że problemem staje się dopiero przypisanie potencjalnemu sprawcy skutku dalszego, a zarazem tego, w którym faktycznie ziściło się skumulowane ryzyko, to jest naruszenia dobra prawnego. Będzie ono dopuszczalne i zasadne zawsze, gdy jego bezprawne zachowanie miało albo przeważający wpływ na nastąpienie skutku, albo chociażby równy wpływ z bezprawnym zachowaniem pokrzywdzonego, co można by roboczo określić jako układ „50 i w górę” (50+). Przy proporcji, w której ten wpływ jest zdecydowanie niższy wobec wpływu pokrzywdzonego, ponieważ ryzyko wywołane bezprawnym zachowaniem potencjalnego sprawcy albo było relatywnie niewielkie (choć rzecz jasna wystarczające do wypełnienia przesłanek pozytywnych), albo prowadziłoby do powstania zupełnie innego i łagodniejszego skutku niż ten, który się urzeczywistnił, przypisanie pozostaje możliwe jedynie w granicach narażenia dobra prawnego na niebezpieczeństwo, co miałoby odpowiadać granicom warunków pozytywnych.

Zaproponowane rozwiązanie wydaje się jednak opierać przede wszystkim na schemacie argumentacyjnym, jaki — ze względu na szacowanie wystąpienia natężenia tych samych stanów rzeczy u obu wchodzących w grę podmiotów - można by określić jako ilościowy. Rzecz jednak w tym, że tego rodzaju wypowiedzi o proporcjach, zwłaszcza przy szczególnej pozycji postępującego ryzykownie dysponenta dóbr prawnych, należałoby skonfrontować z ujęciem, które dałoby się wstępnie określić jako jakościowe. Inspiracji w tym zakresie zaś można poszukiwać w niektórych rozwiązaniach kwestii udziału pokrzywdzonego w stworzeniu prawnokarnie relewantnego niebezpieczeństwa postulowanych w doktrynie niemieckiej.

udaremniłoby takie następstwa, które ostatecznie miałyby miejsce" — M. Bielski, Obiektywne przypisanie..., s. 87. 
Za punkt wyjścia w omawianym obszarze zwykle przyjmuje się rozróżnienie między tak zwanym samonarażeniem się ofiary oraz „narażeniem ofiary na niebezpieczeństwo wywołane za jej zgodą przez inną osobę", oparte na wiodącej przesłance panowania nad przebiegiem całego zdarzenia, co ma odpowiadać wymogom dotyczącym konstrukcji sprawstwa, a nie jedynie udziału w cudzym czynie $^{14}$. O ile zatem dysponenta dobra prawnego skłonni bylibyśmy określić jako sprawcę czynu skierowanego przeciwko niemu samemu, mającego możliwości decyzyjne i wykonawcze pozwalające mu ukształtować dany przebieg przyczynowy wedle jego woli, o tyle aktualizowałaby się przesłanka określana jako samonarażenie się pokrzywdzonego, przeciwstawna zgodzie na narażenie pochodzące od osoby trzeciej, której sprawczemu zachowaniu dysponent dobra jedynie się poddaje lub z niego korzysta.

Sens takiego rozróżnienia wyraża się głównie w tym, że w pierwszym przypadku ofiara cały czas panuje nad sytuacją, decydując o tym, jak dalece własnym działaniem chce się narażać na niebezpieczeństwo, podczas gdy w przypadku drugim chodzi jedynie o tolerowanie narażenia pochodzącego od innej osoby, którego dalszy rozwój jest niekiedy trudny do przewidzenia, możliwości zaś ingerencji ofiary w przebieg wydarzeń często bardzo ograniczone ${ }^{15}$.

Właściwe przeprowadzenie takiego rozgraniczenia staje się o tyle kluczowe, że konsekwencją dokonanej kwalifikacji przypadku ma być obranie zupełnie odmiennych sposobów, a nawet płaszczyzn, oceny. Autonomiczność zachowania się pokrzywdzonego w sytuacjach akceptacji przez niego narażenia pochodzącego z zewnątrz, od innej osoby, podlega badaniu z perspektywy uwarunkowań zaistnienia zgody dysponenta dobra prawnego ${ }^{16}$. Drugi z wariantów — z uwagi na panowanie nad przebiegiem zdarzenia przez samą ofiarę — podlega generalnej regule braku możliwości przypisania skutku, ponieważ to przede wszystkim sama ofiara, a nie inna z osób uczestniczących w rozważanej konstelacji wielopodmiotowej, naraziła się na niebezpieczeństwo lub na uszczerbek w swoich dobrach.

Kryterium „panowania”, mimo aspektu ilościowego, już intuicyjnie kojarzy się również z jakąś różnicą jakościową. Panuje mianowicie ten, kogo wpływ na przebieg i ostateczny efekt zagrożenia jest zasadniczy, kluczowy, nie tylko zaś większy od wpływu innych. Potwierdzają to także konstruowane (skądinąd nie-

14 Przekonująca wydaje się jednak argumentacja, że kto sam naraża swoje dobra, nawet jeżeli czyni to w pełni świadomie, w istocie nie chce przecież tych dóbr utracić czy unicestwić, zatem odwołanie do dogmatyki form współdziałania przestępnego jest chybione. Zarówno bowiem podmiot kwalifikowany jako sprawca, jak i współdziałający mają nadzieję, że niebezpieczeństwo się jednak nie urzeczywistni w skutku - por. I. Puppe, Die Lehre von der objektiven Zurechnung und ihre Anwendung - Teil 2, „Zeitschrift für das Juristische Studium” 2008, z. 6, s. 605.

15 J. Giezek, [w:] System Prawa Karnego, t. 3, s. 513.

16 U. Murmann, Grundkurs Strafrecht, München 2017, s. 183. Zagadnienie właściwego przedmiotu i skuteczności takiej zgody w kontekście choćby rodzaju dóbr prawnych i uprawnienia do dysponowania nimi, rozróżnienia na zgodę na narażenie a zgodę na uszczerbek itp. jest niezwykle złożone i sporne — por. J. Giezek, [w:] System Prawa Karnego, t. 3, s. 518 n. 
kiedy bardzo kazuistycznie) wyjątki pozwalające na odwrócenie pozycji kandydatów do przypisania, która wynikałaby wyłącznie z pierwotnego porównania ich udziału w czynie. Mimo bowiem ewidentnego samonarażenia się ofiary konieczne jest też stwierdzenie postępowania przez nią „,na własną odpowiedzialność”. Owa przesłanka (niem. Eigenverantwortlichkeit) zawiera zaś w sobie cały szereg dalszych warunków odnoszących się do charakterystyki - wprawdzie przeważającego — wkładu w sytuację ryzykowną, w którym jednak muszą ujawniać się również wymagane cechy jakościowe.

Ilustracją powyższego może być przykład uzależnionego od heroiny pacjenta, który zmarł w wyniku przedawkowania fentanylu uzyskanego przez siebie z plastrów przeciwbólowych, które przepisał mu — bez stosownych badań i kontroli — jego lekarz ${ }^{17}$. Wprawdzie to pacjent cały czas w przeważającym stopniu przedmiotowo sterował niebezpieczeństwem (wyłudzając plastry, otrzymując z nich w drodze dalszych procesów chemicznych substancję odurzającą i wreszcie robiąc sobie feralny zastrzyk), jednak samodzielność jego procesów wolicjonalnych i intelektualnych, możliwość obejmowania przez niego całości wytworzonego ryzyka i jego ziszczenia się w skutku, mogła budzić wątpliwości, otwierając tym samym drogę do odpowiedzialności lekarza. Obie z dwóch proponowanych interpretacji przesłanki samodzielności, suwerenności samonarażenia, to jest zgodnie z koncepcją opierającą się na wymogach odnoszących się do zgody dysponenta dobrem prawnym (wówczas dokonuje się porównania zachowania samonarażającej się ofiary z hipotetycznie podstawionym narażeniem jej przez osobę trzecią za jej zgodą i bada, czy owa zgoda została wyrażona w sposób świadomy i dobrowolny — innymi słowy, czy „wewnętrzna aprobata dla zagrożenia odznaczała się tego rodzaju stanowczością woli i ukierunkowaniem na cel, że ofiara musiała pozostawać w świadomości znaczenia i konsekwencji swojej decyzji"18) lub analogii do okoliczności decydujących o wyłączeniu winy (w tym zakresie nie mogą działać „na własną odpowiedzialność” osoby niepoczytalne czy małoletnie, lecz

17 Przykład został zaczerpnięty z orzeczenia Trybunału Federalnego (BGH) z dnia 16 stycznia 2014 roku, 1 StR 389/13, NStZ 2018, 577 (tak zwane Schmerzpflaster-Fall) — lekarz, lecząc przez kilka lat uzależnionego od heroiny pacjenta, był — jak ustalono — w pełni świadomy, że uzależnieni pacjenci często wymuszają przepisywanie im silnych środków przeciwbólowych lub oszukują, aby otrzymać na nie receptę i uzyskać z nich następnie substancje odurzające. Miał też wiedzę na temat konieczności zachowania szczególnej lekarskiej kontroli przy stosowaniu przez pacjenta plastrów przeciwbólowych z tak silną substancją, jaką jest fentanyl. Mimo tego, gdy pacjent po dłuższej przerwie zjawił się w jego gabinecie, uskarżając się na ostry ból kręgosłupa i pokazując wspomniany plaster, przepisał mu — bez dokonania badań — dziesięć dalszych plastrów z fentanylem, a następnie — również przy braku badań — dziesięć kolejnych. Pacjent uzyskał z plastrów fentanyl, po czym wstrzyknął sobie śmiertelną dawkę substancji. Przedmiotem rozważań sądu była odpowiedzialność lekarza za sprowadzenie uszczerbku na zdrowiu z następstwem w postaci śmierci z § 227 StGB (odpowiednik art. $156 \S 3$ k.k.).

18 H. Schneider, [w:] Münchener Kommentar zum Strafgesetzbuch, t. 4, red. W. Joecks, K. Miebach, München 2012, s. 710. Interpretacja tego kryterium czerpie też swoje źródło z wymogów stawianych żądaniu pokrzywdzonego przy zabójstwie eutanatycznym.

Przegląd Prawa i Administracji CXX, 2020, cz. 1 i 2

(C) for this edition by CNS 
także ograniczona zdolność do ponoszenia winy zasadniczo wyklucza możliwość traktowania samonarażenia jako autonomicznego) prowadziłyby w omawianym kazusie do tożsamego rezultatu, którym byłoby zakwestionowanie wyłączającego odpowiedzialność lekarza zachowania uzależnionego pokrzywdzonego ${ }^{19}$. Uzależnienie pacjenta narkomana wykluczało przede wszystkim pełne uświadomienie sobie przez niego rozmiarów i następstw ryzyka, a tym samym zaaprobowanie ich w takiej właśnie postaci, w jakiej się one rzeczywiście przejawiły, a w konsekwencji (lub przynajmniejej ${ }^{20}$ dostosowanie do poprawnie rozpoznanego ryzyka swojego postępowania. Zresztą przytoczonych elementów można by poszukiwać już w samym pierwotnym pojęciu panowania, w istocie ten tylko może nad czymś panować, kto czyni to „w pełnej świadomości”21.

Zaprezentowana argumentacja skłania do postawienia tezy, że nawet jeżeli zachowanie dysponenta dobrem jawi się jako zdecydowanie dominujące nad zachowaniem tak zwanego potencjalnego sprawcy (drugiego z kandydatów do przypisania), to wynikające z samego porównania wielkości udziałów tychże podmiotów w ryzyku rozłożenie pomiędzy nimi odpowiedzialności może zostać podważone wystąpieniem dodatkowych czynników (przesłanek), jak choćby wspomniana suwerenność decyzyjna ${ }^{22}$. Pojawia się wtedy pewna przewaga jakościowa danego

19 Por. M. Lasson, Eigenverantwortliche Selbstgefährdung und einverständliche Fremdgefährdung. Überblick über einen nach wie vor aktuellen Streit in der Strafrechtsdogmatik, „Zeitschrift für Juristische Studium” 2009, nr 4, s. 362-363.

${ }^{20}$ W nawiązaniu do koncepcji ekskulpacyjnej można uznać, że sprawca, nawet zdając sobie sprawę z określonego stanu rzeczy i prawidłowo rozpoznając ryzyko, może nie być w stanie pokierować swoim postępowaniem.

${ }^{21} \mathrm{~W}$ piśmiennictwie niemieckim często można spotkać w tym kontekście zwrot sehenden Auges, a zatem ten tylko panuje nad niebezpieczeństwem, kto staje wobec niego z „otwartymi oczami”. Nie jest natomiast wymogiem, aby decyzja dysponenta obiektywnie jawiła się jako rozsądna, wręcz przeciwnie - w sytuacji gdy dysponent w sposób głęboko irracjonalny odmawia poddania go zabiegom, które mogłyby odwrócić lub zmniejszyć zagrożenie dla jego dóbr prawnych (przykładowo ciężko ranny odmawia poddania go wymaganej transfuzji krwi), to kryterium nieracjonalności zachowania pokrzywdzonego staje się właśnie podstawą do przypisania jemu, a nie innej osobie (nawet będącemu gwarantem lekarzowi) odpowiedzialności za skutek. Na marginesie można wskazać, że kryterium to jest wyjątkowo niejasne i może prowadzić do skrajnie przeciwstawnych rozstrzygnięć - przykładowo odmowa poddania się operacji z uwagi na śmiertelność w przedziale 5-15\% nie została uznana za nieracjonalną — wyrok OLG Celle z dnia 14 listopada 2000 roku, 32 Ss 78/00, NJW 01, 2816; nie wyłączono zaś odpowiedzialności lekarza, gdy znajdujący się w stanie nietrzeźwości, ciężko ranny pacjent odmówił leczenia szpitalnego, aby udać się do domu w celu dalszego spożywania alkoholu — wyrok BGH z dnia 9 marca 1994 roku, 3 StR 711/93, NStZ 94, 394.

${ }^{22} \mathrm{~W}$ charakterze jedynie zasygnalizowania pewnego zagadnienia można by w tym momencie zastanowić się, czy w jakimś stopniu zbieżny trop argumentacyjny można by zrekonstruować, opierając się na wskazywanej wcześniej tak zwanej zmiennej w postaci statycznego lub dynamicznego charakteru niebezpieczeństwa. Wszak sens jej wyróżniania sprowadza się do wpływu, jaki rodzaj niebezpieczeństwa ma na procesy intelektualne i decyzyjne osoby, która ma na owo niebezpieczeństwo zareagować, a nie tylko w oddaniu różnych wariantów czasowego następstwa zachowań pokrzywdzonego i osoby trzeciej. Innymi słowy, chodzi o różnice w odbiciu w świadomości sprawcy wszystkich elementów zagrożenia w wypadku, gdy już ono istnieje i daje się w pełni zidentyfiko- 
zachowania, co więcej - to czynniki związane ze świadomością i wolą podmiotu mogą nabrać krytycznego znaczenia przy przypisaniu wszak obiektywnym ${ }^{23}$. Konieczność wręcz odwołania się do czegoś więcej niż porównywań ilościowych może zaś mieć miejsce w tych szczególnie skomplikowanych konstelacjach, które cechuje na pierwszy rzut oka pewna równowartość zaangażowania i ryzyk wytworzonych zarówno przez pokrzywdzonego, jak i drugą osobę, czyli swoisty „remis”.

Jako przykłady podobnych układów niepozwalających na ich jednoznaczne zakwalifikowanie do wybranej kategorii narażenia ${ }^{24}$ wskazuje się zwłaszcza tak zwane przypadki ratownicze oraz wspólne próby samobójcze, jak choćby słynny Gisela-Fall, w którym dwoje nieszczęśliwie zakochanych młodych ludzi postanowiło się razem zabić, zamykając obieg spalin w samochodzie. Mężczyzna naciskał na pedał gazu, podczas gdy dziewczyna siedziała na miejscu pasażera. Ona pierwsza straciła przytomność, on zaś nie przerwał swojego zachowania mimo nieprzytomności partnerki, zapewniając dalszy dopływ mieszanki paliwowej do silnika i kontynuował je, aż do własnej utraty przytomności. Ponieważ ostatecznie mężczyznę zdołano uratować, sąd stanął przed dylematem, na ile można go obciążyć odpowiedzialnością za śmierć dziewczyny ${ }^{25}$.

wać, a rozwija się, ewoluuje i tym samym jest trudniejsze do rozpoznania. Zarówno M. Bielski, jak i J. Giezek wskazują zresztą na ten aspekt w powiązaniu z przesłanką rozpoznawalności ryzyka. Tym samym ten, kto mając możliwość rozpoznania statycznego niebezpieczeństwa, zachowuje się mimo tego w sposób sprzyjający wystąpieniu negatywnego skutku, musi liczyć się z ewentualnością normatywnego powiązania właśnie jego obiektywnie niewłaściwego postępowania z owym skutkiem. Jeżeli natomiast zachowanie nie stanowiłoby reakcji na już istniejące niebezpieczeństwo, ale zmiany prowadzące do powstania takiego niebezpieczeństwa dopiero by zachodziły, a zatem cała sytuacja odznaczałaby się dynamizmem znacznie utrudniającym poprawne rozpoznanie zagrożenia i wdrożenie odpowiednich środków zaradczych przez jednostkę, to skłonni bylibyśmy znacznie łagodzić odpowiedzialność potencjalnego sprawcy — por. J. Giezek, [w:] System Prawa Karnego, t. 3, s. 511, 520; M. Bielski, Obiektywne przypisanie..., s. 86 n. Ponadto „[w] przypadku dynamicznego źródła niebezpieczeństwa konieczność natychmiastowej reakcji na zagrożenie znacząco utrudnia innej osobie podjęcie zachowań minimalizujących możliwość urzeczywistnienia się zaistniałego niebezpieczeństwa w skutku przestępnym" — idem, O potrzebie..., s. 277.

${ }^{23}$ Co stanowi niezwykle interesujący, choć niestety zdecydowanie przekraczający ramy niniejszego opracowania przyczynek do dyskusji o czysto przedmiotowym charakterze kryteriów przypisania obiektywnego i jego wyraźnej opozycji do przypisania subiektywnego, czy też pewnym przenikaniu się przesłanek z obu normatywnych płaszczyzn wartościowania — por. J. Giezek, P. Kardas, op. cit., s. 18 n; zob. też M. Bielski, O potrzebie..., s. 283.

${ }^{24}$ Należy mieć na uwadze, że przypadki te mogą — od strony wskazywanych już wcześniej koncepcji, by to samonarażenie stanowiło właściwy problem obiektywnego przypisania, zgoda zaś na narażenie przez inną osobę była badana w aspekcie bezprawności zachowania — nastręczać wyjątkowe trudności, choćby z obraniem stosownej do wartościowania płaszczyzny w dogmatycznej strukturze przestępstwa - por. A. Grünewald, Selbstgefährdung und einverständliche Fremdgefährdung, „Goltdammer's Archiv für Strafrecht” 2012, nr 159, s. 368 n.

25 Wyrok BGH z dnia 14 sierpnia 1963 roku, 2 StR 181/63, BGHSt 19, 135. Istnienie w polskim porządku prawnym unormowania art. 151 k.k. nie rozwiewa wątpliwości związanych z powyższym układem i pozostawia jako podstawy wartościowania poszczególnych przypadków również normy z art. 149 i 148 k.k. związanych ze wskazanym układem. Por. w tym zakresie interesujące 
Próba rozwiązania tego problemu za pomocą wskazania przewagi w postaci „panowania nad niebezpieczeństwem” zdaje się doprowadzać do przynajmniej wątpliwych rezultatów. Tak samo bowiem mało przekonuje ostatecznie dokonane przez sąd ustalenie, że naciskanie przez mężczyznę aż do chwili utraty przytomności pedału gazu kreowało sprawstwo po jego stronie, podczas gdy Gisela jedynie znosiła, tolerowała własną śmierć (mimo że póki pozostawała przytomna, miała pełną swobodę opuszczenia auta), jak przeważający w literaturze pogląd o potrzebie przeformułowania kryterium panowania nad niebezpieczeństwem na „panowanie nad momentem sprowadzającym śmierć”, implikujący uznanie, że samobójstwa dopuszcza się ten, kto w krytycznym punkcie czasowym, po którym nie ma już odwrotu, nadal ma kontrolę nad swoim losem, kto samodzielnie przekracza ową linię graniczną, poza którą będzie już niezdolny do czynu ${ }^{26}$. Symptomatyczne jest zresztą szukanie rozgraniczenia między możliwością przypisania skutku śmiertelnego a uznaniem samobójstwa ofiary w elementach odnoszących

uwagi dotyczące odpowiedzialności sprawcy za zachowanie odpowiadające od strony podmiotowej przestępstwu zabójstwa eutanatycznego - P. Konieczniak, W sprawie eutanatycznej pomocy do samobójstwa (na marginesie sporu J. Warylewski-K. Poklewski-Koziett), „Państwo i Prawo” 1999, nr 5, s. 75; J. Malczewski, Problemy z prawna kwalifikacja lekarskiej pomocy do samobójstwa (art. 151 k.k.), „Prokuratura i Prawo” 2008, nr 11, s. 27; J. Kosonoga-Zygmunt, Namowa i udzielenie pomocy do samobójstwa (art. 151 k.k.), „Prokuratura i Prawo” 2015, nr 11, s. 62-63, choć jak w przypadku ostatniego z opracowań problem obiektywnego przypisania, choć zauważalny i określany jako istotny, zwłaszcza w kontekście nacechowania kauzalnego znamienia czynnościowego „doprowadza”, jest w kontekście inicjatywy samego suicydenta sprowadzany do okoliczności mającej znaczenie jedynie dla wymiaru kary, co wymaga jednak poczynienia pewnego zastrzeżenia. Zaistnienie bowiem „przyczynienia” się pokrzywdzonego w określonych konfiguracjach może — nie doprowadzając do modyfikacji po stronie osoby, z którą wiązane jest sprawstwo skutku — znajdować swój ostateczny rezultat właśnie w zmianie wymiaru kary — precyzyjniej poprzez zmianę stopnia społecznej szkodliwości (por. M. Bielski, Obiektywne przypisanie..., s. 87-89). Ponadto istotnego znaczenia nabiera też problematyka przypisania w odniesieniu do kryteriów związanych z możliwymi formami współdziałania przestępnego na tle art. 151 k.k. — por. obszernie Ł. Pohl, Kierowanie wykonaniem samobójstwa oraz polecenie jego wykonania w polskim prawie karnym (analiza de lege lata $i$ postulaty de lege ferenda), [w:] Teoretyczne i praktyczne problemy współczesnego prawa karnego. Księga Jubileuszowa dedykowana Profesorowi Tadeuszowi Bojarskiemu, red. A. MichalskaWarias, I. Nowikowski, J. Piórkowska-Flieger, Lublin 2011, s. 525 n.; K. Burdziak, Kierowanie wykonaniem samobójstwa i polecenie jego wykonania w polskim prawie karnym, „Ruch Prawniczy, Ekonomiczny i Socjologiczny" 2014, z. 4, s. 175 n. W razie samobójstw zbiorowych art. 151 uważa się za znajdujący zastosowanie, ale w zbiegu kumulatywnym z podżeganiem lub pomocnictwem do zabójstwa, lecz gdy sprawca po zabiciu innej osoby popełnia następnie samobójstwo — por. B. Michalski, [w:] Kodeks karny. Część szczególna, t. 1. Komentarz do artykułów 117-221, red. A. Wąsek, R. Zawłocki, Warszawa 2010, s. 310; A. Zoll, [w:] Kodeks karny. Część szczególna, t. 2. Komentarz do art. 117-211a, red. A. Zoll, Warszawa 2017, s. 322-324.

${ }^{26}$ Doprowadziło to przykładowo C. Roxina do uznania, że Gisela — poprzez wdychanie spalin aż do chwili utraty przytomności — „sama przekroczyła wrota śmierci” — idem, Täterschaft und Tatherrschaft, München 2015, s. 571; zob. też C.H. Jäger, [w:] Streitbare Strafrechtswissenschaft. Festschrift für Bernd Schünemann zum 70. Geburtstag am 1. November 2014, red. R. Hefendehl, T. Hörnle, L. Greco, Berlin-Boston 2014, s. 423. 
się do wskazywanych wcześniej kryteriów zgody dysponenta dobrem prawnym oraz analogicznie stosowanych przesłanek winy lub jej wyłączenia, a nawet — jak proponuje U. Murmann - wręcz w odniesieniu do przesłanek właściwych jednak zwykle przypisaniu subiektywnemu przestępstw nieumyślnych ${ }^{27}$.

Jeszcze mocniej omawianą kwestię unaocznia się w zagadnieniu ewentualnego przypisywania odpowiedzialności osobie, która stworzyła wyjściowe zagrożenie, za uszczerbek, jaki odniósłby niosący pomoc ratownik. Jeżeli bowiem lekkomyślny turysta utknie w załomie skalnym, stworzy tym samym niedopuszczalne niebezpieczeństwo dla ratownika górskiego. Przyjmując — co skądinąd także jest sporne - że mielibyśmy do czynienia z zasadniczym samonarażeniem się interweniującego ratownika ${ }^{28}$, uzasadnia się jednak odpowiedzialność twórcy wyjściowego niebezpieczeństwa za wszelkie dalsze konsekwencje jego zachowania zaistniałe na dobrach ratownika tym, że zawodowy ratownik nie może, z uwagi na ciążące na nim obowiązki gwaranta, swobodnie i samodzielnie decydować o narażeniu się na ryzyko, jego zachowanie jest zatem w tym zakresie zawsze zdeterminowane. Ponownie więc aktualizuje się tu argument suwerenności decyzyjnej, rozstrzygający dla uznania, że ewentualnie pokrzywdzony działał na własną odpowiedzialność. Sytuacja ulega ponownemu zwrotowi, jeżeli ratownik przekroczy swoim zachowaniem pewien poziom ryzykowności czynności ratowniczych, który dałoby się uzasadnić wymogiem ich proporcjonalności ${ }^{29}$. Zachowanie ratownika przestaje być wówczas typowo powiązane z pierwotnym niebezpieczeństwem i nie będąc dłużej przewidywalne dla pierwotnego sprawcy, nie implikuje

27 Tak, w opozycji do różnych form uchwycenia panowania nad czynem: U. Murmann, Selbstverantwortung des Opfers im Strafrecht, Heidelberg-London-New York 2005, s. 337 n.; idem, Zur Einwilligungslösung bei der einverständlichen Fremdgefährdung, [w:] Strafrechtswissenschaft als Analyse und Konstruktion. Festschrift für Ingeborg Puppe zum 70. Geburtstag, red. C.H. Paeffgen et al., Berlin 2011, s. 773; por. T. Walter, Die Lehre von der ,, einverständlichen Fremdgefährdung”" und ihre Schwächen - eine Verteidigung der Rechtsprechun, „Neue Zeitschrift für Strafrecht” 2013, s. 675. W odniesieniu do art. 151 k.k. zob. przykładowo uwagi co do swobody decyzyjnej jako przesłanki odpowiedzialności za namowę lub pomoc do samobójstwa i kwalifikacje w zakresie świadomości, którymi musi odznaczać się przedmiot czynności wykonawczej tego przestępstwa - A. Wąsek, Prawnokarna problematyka samobójstwa, Warszawa 1982, s. 73-74; M. Budyn-Kulik, [w:] System Prawa Karnego, t. 10. Przestepstwa przeciwko dobrom indywidualnym, red. J. Warylewski, Warszawa 2016, s. 150; M. Mozgawa, P. Bachmat, Przestepstwo namowy lub udzielenia pomocy do samobójstwa (art. 151 k.k.), „Ius Novum” 2017, $\mathrm{nr}$ 2, s. 73-74; R. Kokot, [w:] Kodeks karny. Komentarz, red. R.A. Stefański, Warszawa 2017, s. 930-931; A. Zoll, op. cit., s. 322-323; J. Kosonoga-Zygmunt, Swoboda decyzji woli suicydenta jako przestanka odpowiedzialności karnej za przestępstwo z art. 151 k.k., „Kwartalnik Prawa Publicznego” 2015, nr 2, s. 24 n.

28 Por. M. Heinrich, [w:] Nomos Kommentar..., s. 179; o ich niejednoznaczności kategorialnej jednak - H. Satzger, Die sog. „Retterfälle” als Problem der objektiven Zurechnung, „Juristische Ausbildung" 2014, nr 7, s. 698.

29 O uznaniu czynności ratunkowych za proporcjonalnie ryzykowne decyduje porównanie wszystkich konkretnych okoliczności danego przypadku, zwłaszcza stopnia zagrożenia ratowanych dóbr prawnych, ich wartości, szans na odwrócenie niebezpieczeństwa oraz stopnia i prawdopodobieństwa naruszenia dóbr ratownika - H. Satzger, op. cit., s. 704. 
dopuszczalności przypisania mu odpowiedzialności za skutki, które z niego wyniknęły. Analogicznie w odniesieniu do ratowników wolontariuszy — na przykład przechodnia, który rzuciłby się z pomocą - decydującą rolę odgrywa to samo powiązanie z wyjściowym niebezpieczeństwem, pozwalające uznać ingerencję za typowo i przewidywalnie uzasadnioną jego wystąpieniem lub też wynikającą z nadzwyczajnej i niespodziewanej brawury lub gotowości do samopoświęcenia.

Prowadzonych tu rozważań, z konieczności przybierających najczęściej formę jedynie zasygnalizowania pewnych obszarów problemowych, nie sposób zamknąć jedną konkluzją czy choćby wyrazami nadziei na rychłe precyzyjne konturowanie zakresów odpowiedzialności w złożonych układach kumulacji ryzyk, gdy jednym z ich twórców staje się sam pokrzywdzony. Warto być może jednak poddać pod rozwagę różnicę między jedynie ilościowym a jakościowym ujęciem zagadnienia wyważania „udziałów” w niebezpieczeństwie, a przy zaaprobowaniu propozycji nieograniczania się tylko do tego pierwszego zastanowienia się nad kryteriami nawiązującymi do uwarunkowań suwerenności decyzyjnej. Tamą dla takiej ścieżki teoretycznych poszukiwań nie powinien być natomiast zarzut „przemycania” elementów subiektywnych do przypisania wszak obiektywnego, gdyż od dłuższego czasu wyrażane są wszelakie wątpliwości co do jego „czystości kategorialnej”"30, interesująco zaś daje się w tym kierunku rozwinąć choćby przewidywalność nieakceptowalnego prawdopodobieństwa skutku.

\title{
SOME PROBLEMS WITH DETERMINING THE SCOPE OF CRIMINAL LIABILITY OF THE POTENTIAL OFFENDER AND THE VICTIM IN THE DOCTRINE OF OBJECTIVE IMPUTATION OF A RESULT
}

\author{
Summary
}

Under criminal law doctrine objective imputation theory is established as an additional filter besides causality, according to which the offender's conduct must have created a wrongful risk of a specific result, and the result must be the product of this very risk. Applying the "wrongful risk" formula becomes particularly problematic in configurations of many people, when the final risk arises as a result of the accumulation of conducts of various actors, including the victim of the crime itself. This paper focuses on the criteria for determining the scope of liability in such situations and is a proposal to complement purely quantitative comparisons. In the latter task, it presents some considerations of German authors, especially on the autonomy in making decisions by the victim.

Keywords: criminal law, objective imputation in criminal law, delimitation of "wrongful risk", victim and criminal liability

30 Zob. np. L. Greco, Das Subjektive an der objektiven Zurechnung: Zum „Problem” des Sonderwissens, „Zeitschrift für die Gesamte Strafrechtwissenschaft” 2005, nr 3, s. 519 n. 


\section{BIBLIOGRAFIA}

Bielski M., Kryteria obiektywnego przypisania skutku na tle wspótczesnej polskiej dogmatyki prawa karnego, [w:] Państwo prawa i prawo karne. Ksiega jubileuszowa Profesora Andrzeja Zolla, red. P. Kardas, T. Sroka, W. Wróbel, t. 2, Warszawa 2012.

Bielski M., O potrzebie teoretycznej, dogmatycznej i kryminalnopolitycznej refleksji nad negatywnymi przesłankami obiektywnego przypisania skutku przestepnego, [w:] Obiektywne oraz subiektywne przypisanie odpowiedzialności karnej, red. J. Giezek, P. Kardas, Warszawa 2016.

Bielski M., Obiektywne przypisanie skutku przestępnego w przypadku kolizji odpowiedzialności za skutek, „Państwo i Prawo” 2005, nr 10.

Budyn-Kulik M., [w:] System Prawa Karnego, t. 10. Przestępstwa przeciwko dobrom indywidualnym, red. J. Warylewski, Warszawa 2016.

Burdziak K., Kierowanie wykonaniem samobójstwa i polecenie jego wykonania w polskim prawie karnym, „Ruch Prawniczy, Ekonomiczny i Socjologiczny” 2014, z. 4.

Dębski R., Jeszcze o propozycji zakotwiczenia w kodeksie karnym kryteriów obiektywnego przypisania skutku, „Nowa Kodyfikacja Prawa Karnego” 43. Księa jubileuszowa Profesora Tomasza Kaczmarka, red. J. Giezek, D. Gruszecka, T. Kalisz, 2017.

Dębski R., O potrzebie kodeksowych przepisów o obiektywnym przypisaniu skutku, [w:] Meandry prawa karnego i kryminalistyki. Ksiega Jubileuszowa prof. zw. dra hab. Stanistawa Pikulskiego, red. J. Kasprzak, W. Cieślak, I. Nowicka, Szczytno 2015.

Dębski R., O tzw. negatywnych przesłankach obiektywnego przypisania, [w:] Obiektywne oraz subiektywne przypisanie odpowiedzialności karnej, red. J. Giezek, P. Kardas, Warszawa 2016.

Giezek J., [w:] System Prawa Karnego, t. 3. Nauka o przestępstwie. Zasady odpowiedzialności, red. R. Dębski, wyd. 2, Warszawa 2017.

Giezek J., Przyczynowość oraz przypisanie skutku w prawie karnym, Wrocław 1994.

Giezek J., Kaczmarek T., Przeciwko ustawowej regulacji kryteriów obiektywnego przypisania skut$k u$, „Państwo i Prawo” 2013, nr 5.

Giezek J, Kardas P., O kryteriach obiektywnego oraz subiektywnego przypisania z punktu widzenia podstaw odpowiedzialności karnej - uwagi wprowadzajace, [w:] Obiektywne oraz subiektywne przypisanie odpowiedzialności karnej, red. J. Giezek, P. Kardas, Warszawa 2016.

Goeckenjan I., Revision der Lehre von der objektiven Zurechnung, Tübingen 2017.

Greco L., Das Subjektive an der objektiven Zurechnung: Zum „Problem” des Sonderwissens, „Zeitschrift für die Gesamte Strafrechtwissenschaft" 2005, nr 3.

Grünewald A., Selbstgefährdung und einverständliche Fremdgefährdung, „Goltdammer's Archiv für Strafrecht" 2012, nr 159.

Jäger C.H., [w:] Streitbare Strafrechtswissenschaft. Festschrift für Bernd Schünemann zum 70. Geburtstag am 1. November 2014, red. R. Hefendehl, T. Hörnle, L. Greco, Berlin-Boston 2014.

Kardas P., W poszukiwaniu tzw. negatywnych przesłanek obiektywnego przypisania, [w:] Obiektywne oraz subiektywne przypisanie odpowiedzialności karnej, red. J. Giezek, P. Kardas, Warszawa 2016.

Kokot R., [w:] Kodeks karny. Komentarz, red. R.A. Stefański, Warszawa 2017.

Konieczniak P, W sprawie eutanatycznej pomocy do samobójstwa (na marginesie sporu J. Warylewski-K. Poklewski-Koziett), „Państwo i Prawo” 1999, nr 5.

Kosonoga-Zygmunt J., Namowa i udzielenie pomocy do samobójstwa (art. 151 k.k.), „Prokuratura i Prawo" 2015, nr 11.

Kosonoga-Zygmunt J., Swoboda decyzji woli suicydenta jako przesłanka odpowiedzialności karnej za przestepstwo z art. 151 k.k., „Kwartalnik Prawa Publicznego” 2015, nr 2.

Lasson M., Eigenverantwortliche Selbstgefährdung und einverständliche Fremdgefährdung. Überblick über einen nach wie vor aktuellen Streit in der Strafrechtsdogmatik, ,Zeitschrift für Juristische Studium" 2009, $\mathrm{nr} 4$.

Przegląd Prawa i Administracji CXX, 2020, cz. 1 i 2

(C) for this edition by CNS 
Majewski J., Prawnokarne przypisanie skutku przy zaniechaniu (zagadnienia węzłowe), Kraków 1997.

Malczewski J., Problemy z prawna kwalifikacja lekarskiej pomocy do samobójstwa (art. 151 k.k.), „Prokuratura i Prawo” 2008, nr 11.

Michalski B., [w:] Kodeks karny. Część szczególna, t. 1. Komentarz do artykułów 117-221, red. A. Wąsek, R. Zawłocki, Warszawa 2010.

Mozgawa M., Bachmat P., Przestępstwo namowy lub udzielenia pomocy do samobójstwa (art. 151 k.k.), „Ius Novum” 2017, nr 2.

Murmann U., Grundkurs Strafrecht, München 2017.

Murmann U., Selbstverantwortung des Opfers im Strafrecht, Heidelberg-London-New York 2005.

Murmann U., Zur Einwilligungslösung bei der einverständlichen Fremdgefährdung, [w:] Strafrechtswissenschaft als Analyse und Konstruktion. Festschrift für Ingeborg Puppe zum 70. Geburtstag, red. C.H. Paeffgen, M. Böse, U. Kindhäuser, S. Stübinger, T. Verrel, R. Zaczyk, Berlin 2011.

Nomos Kommentar. Gesamtes Strafrecht, red. D. Dölling, G. Duttge, S. König, D. Rössner, Baden-Baden 2017.

Pohl Ł., Kierowanie wykonaniem samobójstwa oraz polecenie jego wykonania w polskim prawie karnym (analiza de lege lata $i$ postulaty de lege ferenda), [w:] Teoretyczne i praktyczne problemy współczesnego prawa karnego. Księga Jubileuszowa dedykowana Profesorowi Tadeuszowi Bojarskiemu, red. A. Michalska-Warias, I. Nowikowski, J. Piórkowska-Flieger, Lublin 2011.

Roxin C., Strafrecht. Allgemeiner Teil, t. 1. Grundlagen. Der Aufbau der Verbrechenslehre, München 2006.

Roxin C., Täterschaft und Tatherrschaft, München 2015.

Satzger H., Die sog. „, Retterfälle” als Problem der objektiven Zurechnung, ,Juristische Ausbildung” 2014, $\mathrm{nr} 7$.

Schneider H., [w:] Münchener Kommentar zum Strafgesetzbuch, t. 4, red. W. Joecks, K. Miebach, München 2012.

Sroka T., Odpowiedzialność karna za niewtaściwe leczenie. Problematyka obiektywnego przypisania skutku, Warszawa 2013.

Tarapata S., Przypisanie sprawstwa skutku $w$ sensie dynamicznym $w$ polskim prawie karnym, Kraków 2019.

Walter T., Die Lehre von der ,einverständlichen Fremdgefährdung” und ihre Schwächen - eine Verteidigung der Rechtsprechun, „Neue Zeitschrift für Strafrecht” 2013.

Wąsek A., Prawnokarna problematyka samobójstwa, Warszawa 1982.

Zoll A., [w:] Kodeks karny. Część szczególna, t. 2. Komentarz do art. 117-211a, red. A. Zoll, Warszawa 2017.

Przegląd Prawa i Administracji CXX, 2020, cz. 1 i 2

(C) for this edition by CNS 